\title{
LIVER AND SERUM SOLUBLE PROTEIN CHANGES AND PATHOMORPHOLOGY IN UNDERNOURISHED MICE WITH ACUTE SCHISTOSOMIASIS MANSONI
}

\begin{abstract}
Eridan M. Coutinho, Frederico G. C. Abath, Lucila P. C. G. de Freitas, Aureni C. Salzano, Maria A. Lapa, Florisbela S. Campos and Eliane B. Melo.

Body, liver and spleen weights; histopathology of the liver, spleen and intestines; hepatic and serum soluble proteins changes were the parameters studied in undernourished Swiss albino mice experimentally infected with $\mathbf{S}$. mansoni. Non-infected deficient animals had lower liver/body weight and spleen/body weight ratios as compared to the controls (22.60\% casein group). Infected mice showed higher values regardless the type of diet. Undernourished infected subgroup showed a persistent exudative periovular reaction in the liver. Soluble hepatic proteins content and serum protein fractions appeared to be lower in the deficient infected mice. A significant difference was detected in the gammaglobulin fraction between infected and non-infected animals fed the control diet with higher values for the former. Our data suggest that the effects of malnutrition, per se, are sometimes more detrimental to the host than those due to Manson's schistosomiasis.
\end{abstract}

Key-words: Schistosoma mansoni. Malnutrition. Mice. Proteins.

The interrelationships between malnutrition and Manson's schistosomiasis have been studied in this laboratory for several years ${ }^{1011} 121314151617181920$.

The use of purified and/or semisynthetic diets for laboratory animals is an artificial way of reproducing clinical, biochemical and pathological findings seen in infected human populations under field conditions. A diet based on human staple foods usually ingested in Norheast Brazil (in areas where schistosomiasis is endemic) was devised. This diet, referred as "Regional Basic Diet" (RBD), when given to wealing mice and rats, induces alterations resembling those found in the marasmatic clinical form of protein energy malnutrition ${ }^{10} 12253233$ which is highly prevalent in Northeast Brazil.

In a previous paper (Coutinho et al, 1991: in press) several indicators of protein nutritional

\footnotetext{
Centro de Pesquisas Aggeu Magalhães/Fundação Oswaldo Cruz e Departamento de Nutrição/Centro de Ciências da Saúde, Universidade Federal de Pernambuco, Recife, PE, Brazil.

Address for correspondence: Dra. Eridan M. Coutinho Centro de Pesquisas Aggeu Magalhães/FIOCRUZ.

Caixa Postal 7472, 50730. Recife, PE, Brazil.

Recebido para publicação em 19/08/91.
}

status were studied in undernourished Swiss albino mice fed RBD and infected experimentally with $S$. mansoni. The purpose of the present investigation was to study the effects of RBD on liver and serum soluble proteins and tissue morphology in the same groups of animals.

\section{MATERIAL AND METHODS}

Animals. Weanling, Swiss albino mice of both sexes were maintained on the three diets (RBD, $7.82 \%$ casein and $22.60 \%$ casein) for 63 days. Twenty mice were studied in each diet and divided into infected and non-infected subgroups.

Animals were housed individually in wire mesh cages, and maintained at $23 \pm 2^{\circ} \mathrm{C}$ with a 12 hour light/12 hour dark cycle.

Diets. The composition of RBD is shown in Table 1. The two control diets (Tables 2 and 3) contained casein at two levels: $7.82 \%$ (control I) and $22.60 \%$ (control II). The control diets were supplemented with mineral salts and vitamin mixture, according to Tagle $\&$ Donoso ${ }^{31}$. The diets were given in pellet form.

Infection. A Schistosoma mansoni strain isolated from São Lourenço da Mata (Pernambuco State, 
Coutinho EM, Abath FGC, Freilas LPCG, Salzano AC, Lapa MA, Campos FS, Melo EB. Liver and serum soluble protein changes and pathomorphology in undernourished mice with acute schistosomiasis mansoni. Revista da Sociedade Brasileira de Medicina Tropical 24:235-243, out-dez, 1991

Table 1 - Composition of the Regional Basic Diet $(R B D)-g / 100 g$

\begin{tabular}{lcccccr}
\hline Components & $\begin{array}{c}\text { Amounts in } \\
\mathrm{g} / 100 \mathrm{~g}\end{array}$ & Proteins & $\begin{array}{c}\text { Carbohy- } \\
\text { drates }\end{array}$ & Fats & Minerals & Fibers \\
\hline Kidney beans (Phaseolus vulgaris) & 18.34 & 3.96 & 10.66 & 0.24 & 0.57 & 1.09 \\
Manioc flour (Manihot esculenta) & 64.81 & 0.82 & 48.59 & 0.12 & 0.43 & 5.64 \\
Salted and dried meat (Charque) & 3.74 & 2.74 & 0.43 & 0.21 & 0.06 & - \\
Fat from salted and dried meat & 0.35 & 0.30 & 9.99 & 0.35 & 0.20 & 0.48 \\
Sweet potato (Iponaea batatas) & 12.76 & 0.03 & 0.95 & 1.26 & 7.21 \\
\hline Total & 100.00 & 7.82 & 69.67 & & & \\
\hline
\end{tabular}

$\mathrm{NDpCal} \%=5.97$

Table 2 - Composition of the control diet $I-g / 100 \mathrm{~g}$

\begin{tabular}{lrrrrrr}
\hline Components & $\begin{array}{c}\text { Amounts in } \\
\text { g/100g }\end{array}$ & Proteins & $\begin{array}{c}\text { Carbohy- } \\
\text { drates }\end{array}$ & Fats & Minerals & Fibers \\
\hline Casein & 8.87 & 7.06 & - & - & - & - \\
Soybean oil & 8.00 & - & - & 8.00 & - & - \\
Water-soluble vitamins & 1.00 & - & - & - & - & - \\
Fat-soluble vitamins & 1.00 & - & - & 1.00 & - & - \\
Salt mixtures & 2.50 & - & - & - & - & 3.50 \\
Cellulose & 3.50 & - & - & - & - & - \\
Corn starch & 75.13 & 7.76 & 74.37 & 7.50 & 3.50 \\
\hline Total & 100.00 & 7.82 & 74.37 & 9.00 & 2.50 & \\
\hline
\end{tabular}

Supplemented with mineral salts and viramin mixtures according to Tagle ${ }^{31}$.

Table 3 - Composition of the control diet II - g/100g

\begin{tabular}{lccccrr}
\hline Components & $\begin{array}{c}\text { Amounts in } \\
\text { g/100g }\end{array}$ & Proteins & $\begin{array}{c}\text { Carbohy- } \\
\text { drates }\end{array}$ & Fats & Minerals & Fibers \\
\hline Casein & 27.80 & 22.09 & - & - & - & - \\
Soybean oil & 13.00 & - & - & 13.00 & - & - \\
Water-soluble vitamins & 1.00 & - & - & 1.00 & - & - \\
Fat-soluble vitamins & 1.00 & - & - & - & 2.50 & - \\
Salt mixtures & 2.50 & - & - & - & - & 4.00 \\
Cellulose & 4.00 & 50.70 & 0.51 & 50.19 & - & 4.00 \\
Corn starch & 100.00 & 22.60 & 50.19 & 14.00 & 2.50 & \\
\hline Total & & & &
\end{tabular}

Supplemented with mineral salts and vitamin mixtures according to Tagle?. 
Coutinho EM, Abath FGC, Freitas LPCG, Salzano AC, Lapa MA, Campos FS, Melo EB. Liver and serum soluble protein changes and pathomorphology in undernourished mice with acute schistosomiasis mansoni. Revista da Sociedade Brasileira de Medicina Tropical 24:235-243, out-dez, 1991

Brazil) and maintained regularly in our laboratory was used. Each animal was infected percutaneously with 80 cercariae shed from Biomphalaria glabrata reared and infected in the laboratory. (Infections up to 100 or 150 cercariae per mouse are well tolerated ${ }^{27}$ 34).

Experimental protocol. Twenty - one days old weanling mice weighing 9 to $12 \mathrm{~g}$ received tap water and diets ad libitum. The body weight was determined every week and the food intake was recorded every day.

Subgroups of 5 mice per control diet were submitted to a pair-feeding trial. So, the daily food intake of control mice (diets II and III) was restricted to the ad libitum intake of RBD - fed animals (diet I).

Soluble Serum and Liver proteins determinations. Blood was collected by aspiration from the axillary vein, allowed to clot and immediately centrifuged at $1.000 \mathrm{x} g$ for 5 minutes. Total protein concentration in serum was determined by the biuret reaction ${ }^{23}$. Electrophoretic studies were carried out in cellulose acetate according to the microzonal system. The liver soluble proteins were determined in homogenates from pieces of the right lobe of the liver, according to Lowry et $\mathrm{ali}^{26}$ and expressed in $\mathrm{mg} /$ total liver weight.

Morphological studies Mice were sacrificed by cervical dislocation. Liver, spleen and both small and large intestines samples were routinely fixed in $10 \%$ buffered formalin, parafin embedded, cut at a six micra thickeness and stained by haematoxylineosin and Mallory's trichrome stains'.

Liver samples were otherwise silver stained by Gomori's techniques to evidentiate the reticulin fibers. Frozen sections were stained with Sudan III to evalute the distribution and morphological quantification of hepatic triglycerides.

Statistical analysis Student's " $t$ " - test and the analysis of variance were used to assess the significance of the data. A statistically significant difference was indicated by a $p<0.05$.

\section{RESULTS}

\section{Quantitative soluble proteins changes}

- Changes in serum soluble proteins. Values for total serum proteins were significantly lower in the infected animals fed the two low - protein diets. Significant differences were always found between mice fed the two low-protein diets as compared to those fed the $22.60 \%$ casein diet regardless $S$. mansoni infection. The albumin fraction had a similar behaviour. The albumins/ globulins $(A / G)$ ratio was decreased in the infected casein-fed groups. An apparent, but not significant, slight distortion was detected in the infected RBD - fed mice as compared to the casein-fed animals. Values for alpha-1 and alpha-2 globulins fractions were significantly lower in RBD - fed infected mice as compared to non-infected ones fed the same diet. Also, the alpha-2 globulin fraction was lower for the infected group fed $7.82 \%$ casein. Only in these animals the beta-globulin fraction was significantly higher. The values for gammaglobulins were significantly higher in the serum of the infected controls (Table 5).

- Changes in liver soluble proteins. Liver proteins measured with the Folin - phenol reagent showed a trend to lower values in infected animals under both low-protein diets (RBD and 7.82\% casein), although these differences were not statistically significant.

Significant results were detected among experimental low-protein and control groups with and without infection, as well as between casein groups (Table 4).

\section{Morphological findings}

- Total body weight, liver and spleen weights/ body weight ratios. At the end of the experiment, a significant differences was detected in the total body weight for low-protein fed mice, with and without infection, the lowest values for RBD - fed infected animals. Infection did not seem to affect the body weight of the control group II (Table 4).

The mean value for liver weights and their standard error for the experimental groups are shown in Table 4. Values for lives weight/total body weight ratio were higher in infected mice. These results were statistically significant, except in the $7.82 \%$ casein - fed group.

Also the mean value for spleen weight and its standard error are seen in Table 4. Values for spleen weight/total body weight ratio were significantly higher for infected mice in all 
Coutinho EM, Abath FGC, Freitas LPCG, Salzano AC, Lapa MA, Campos FS Melo EB. Liver and serum soluble protein changes and pathomorphology in undernourished mice with acute schistosomiasis mansoni. Revista da Sociedade Brasileira de Medicina Tropical 24:235-243, out-dez, 1991
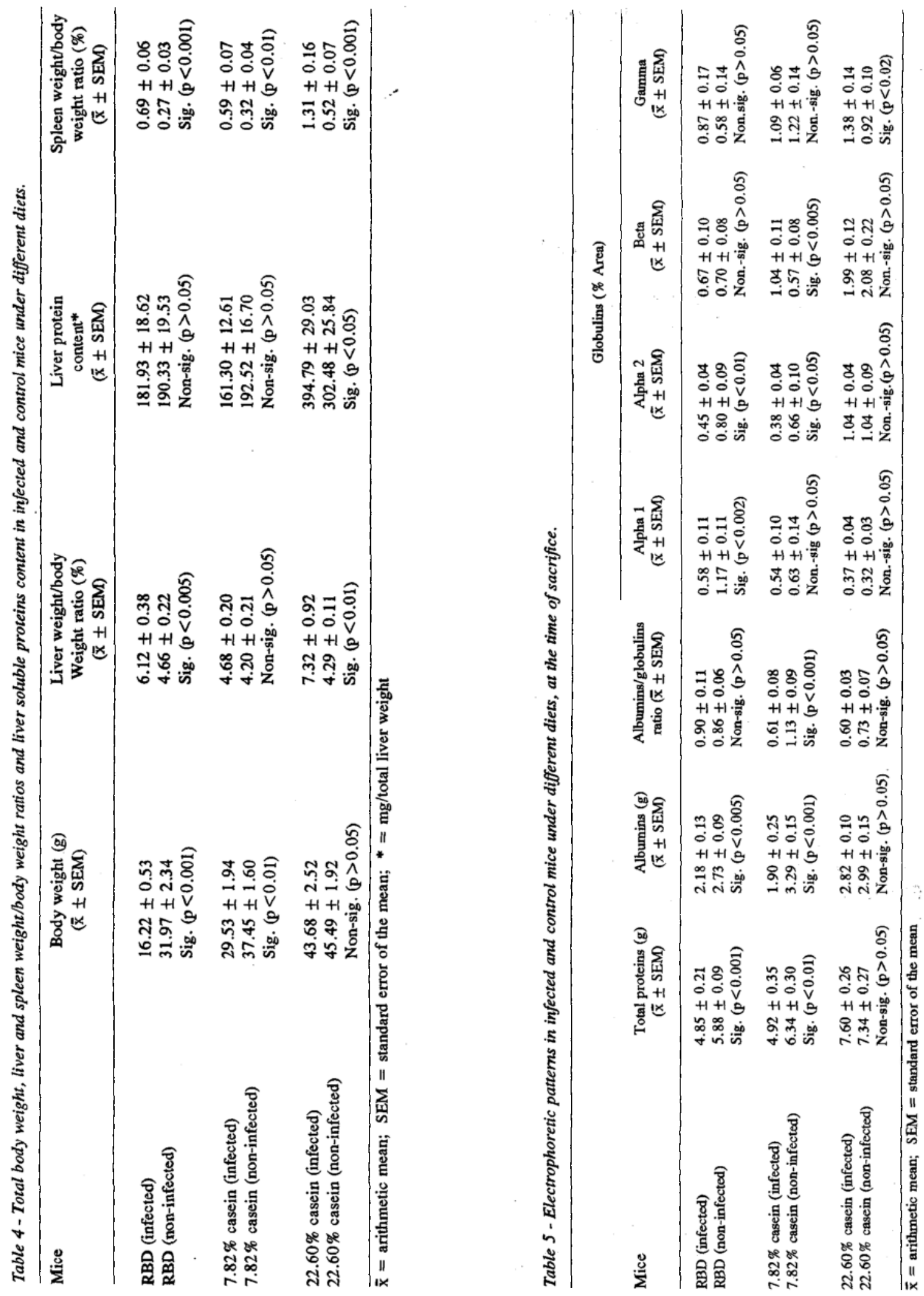
Coutinho EM, Abath FGC, Freitas LPCG, Salzano AC, Lapa MA, Campos FS, Melo EB. Liver and serum soluble protein changes and pathomorphology in undernourished mice with acute schistosomiasis mansoni. Revista da Sociedade Brasileira de Medicina Tropical 24:235-243, out-dez, 1991

experimental groups.

Again, significant results were obtained for both low-protein fed groups when compared to control group II, the highest values for infected animals. But results were not significant when non-infected mice in the two low-protein groups were compared to each other.

- Histopathology. In infected RBD-fed mice, the liver parenchyma showed several periovular granulomas, some of them with a predominantly histiocytic cellular reaction (eggs with a still preserved miracidium), other with an exudative reaction in which neutrophils and many eosinophils zould be detected. Periovular microabscesses, as well as a lasting exudative celullar reaction around both viable and non-viable eggs, could be seen Figure 1). Vacuolar degeneration and diffuse steatosis, particularly of the portal type, were the lesions most frequently observed.

In the intestines, particularly in the jejuno-ileal segment, several fibrotic and/or histicytic rranulomas were seen in the lamina propria of the mucosal layer. However, they were more abundant in the submucosa, where ova agglomerated, inducing an extensive reaction progressing to fibrosis in the wall of the small intestine (Figure
2). Also, a marked eosinophylic infiltration around retained eggs in the submucosa layer could be detected.

The spleen showed a poorly deliniated white pulp, low cellular density of the periarteriolar lymphatic sheaths and Malpighian follicles without reactive centers.

Hepatic lesions in infected mice fed the $7.82 \%$ casein diet (control I) were similar to those reported for RBD-fed infected mice. However steatosis seemed to be milder, exudation of periovular granulomas less apparent and collagenisation of the egg granulomas less delayed in this subgroup.

In infected mice fed a $22.60 \%$ casein diet (control II), the liver parenchyma, as a whole, had a normal aspect, except by the presence of periovular schistosomotic granulomas with a higher cellularity while other granulomas were predominantly of the productive type, with many histiocytes, fibroblasts and collagen fibers (Figure 3 ). Sometimes a focus of acute coagulative necrosis beside small pieces of the eggshell and a peripheral histiocytic reaction could be seen. Eventually, afew cells with fat droplets could be detected in the liver parenchyma.

In the spleen, most of the Malphigian follicles showed reactive centers; periovular granulomas with a histiocytic reaction, sometimes displaying



Figura 1 - Liver of RBD-fed infected mouse: lasting exudative cellular reaction with many eosinophils around a viable egg of $\mathrm{S}$. mansoni showing a degenerated miracidium. $x 400$ (HE) 
Coutinho EM, Abath FGC, Freitas LPCG, Salzano AC, Lapa MA, Campos FS, Melo EB. Liver and serum soluble protein changes and pathomorphology in undernourished mice with acute schistosomiasis mansoni. Revista da Sociedade Brasileira de Medicina Tropical 24:235-243, out-dez, 1991

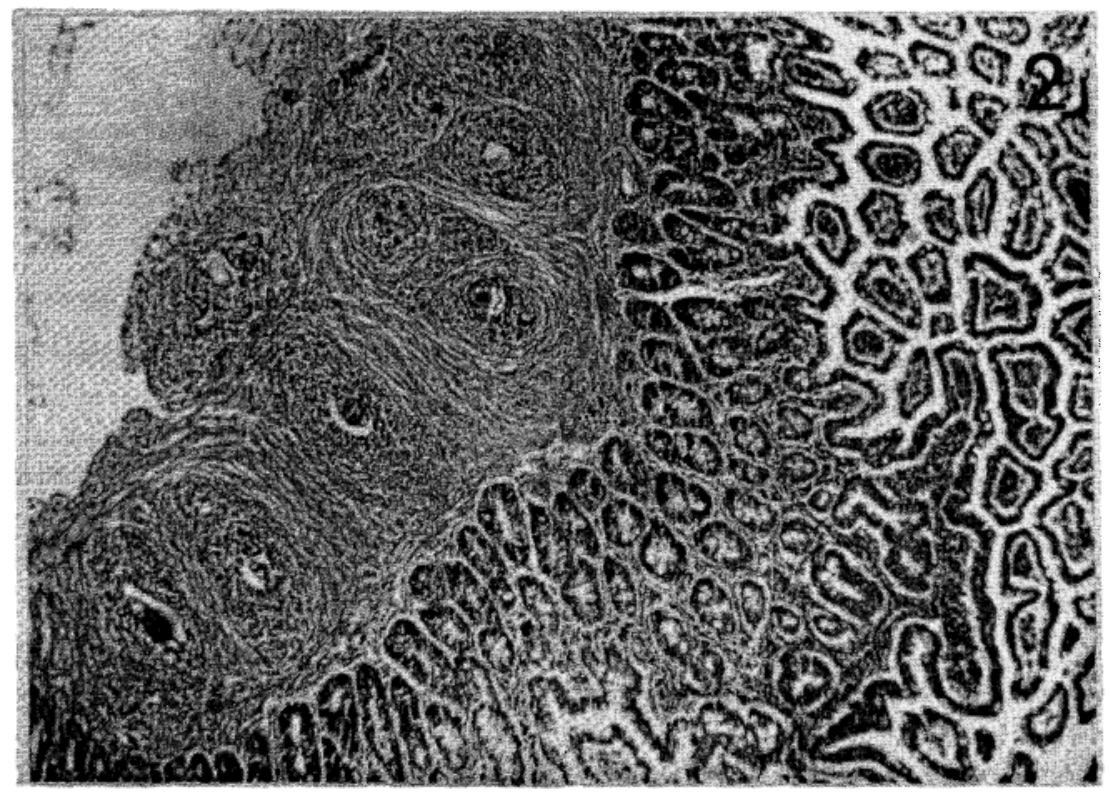

Figura 2 - Small intestine of RBD-fed infected mouse: extensive fibrosis with several periovular granulomas in the submucosa. x63 (HE).



Figura 3 - Liver of $22.60 \%$ Casein-fed mouse: periovular granuloma with histiocytes, fibroblasts and collagen fibers around an egg of S. mansoni showing a degenerated miracidium. $x 400$ (HE).

central coagulative necrosis, could be seen in a hyperemic red pulp. Periovular granulomas were seen in every layer of the small and large intestinal walls. However, they seemed to be more abundant in the submucosa, where they joined each other and induced a diffuse process of fibrosis.

Hepatic lesions in non-infected mice fed the three diets were related to the effects of the level and type of dietary protein; steatosis was a common lesion in the animals on both low protein diets 
(RBD and $7.82 \%$ casein diet).

No clear-cut differences could be detected regarding the spleen and intestine lesions in all the experimental groups.

\section{DISCUSSION}

The public health importance of the relationship between schistosomiasis and nutritional status in human populations is still unclear ${ }^{30}$. Most of the studies on these interactions have involved experimental animals and the use of purified and/ or semisynthetic diets ${ }^{2}$. On the other hand, it is widely accepted that schistosomiasis and malnutrition are mutually interactive problems, that is, both act synergistically ${ }^{21}$, although other reports say just the opposite ${ }^{2}$.

According to our findings, the liver soluble proteins changes showed a trend to lower values in infected mice fed both low-protein diets (RBD and $7.82 \%$ casein control diet) as compared to infected animals fed the $22.60 \%$ casein control diet.

Although the hepatic protein content seems to be better expressed in relation to the hepatic $\mathrm{DNA}^{9}$, it can also be expressed in relation to the total liver weight ${ }^{28}$ as in the present paper. So, one can speculate that due to a probable increase in the amount of oviposition and to the formation of periovular granulomas with a more intensive inflammatory reaction, the high protein content in the liver of the control group represents the amount of a non-specific protein pool in the organ, which is resposible for the higher values obtained in this group when compared to the group of non-infected mice fed the same diet. Probably, the hight values for liver weights in non-infected mice fed the $22.60 \%$ casein diet reflect the better quality of the dietary protein and, in the infected subgroup, $S$. mansoni infection also accounts for this increased weight.

Similarly, the changes in the serum protein levels were more commonly seen in the low protein-fed groups, particularly in RBD-fed mice. On the other hand, a progressive increase in the beta and gammaglobulin fractions, with negligible or inexistent changes in the albumins and alphaglobulin concentrations, would be expected in the serum of control mice ${ }^{22}$.
The liver weight/total body weight and the spleen weight/total body weight ratios were higher in the infected mice, regardless the type of dietary intake, indicating the important role played by schistosomiasis in the occurrence of liver and spleen enlargements in the course of the disease.

Histologically, reduction in cellularity and a lasting exudative periovular reaction seem to occur more commonly in RBD-fed mice as compared to casein-fed ones where most of the periovular granulomas were of the productive (non-exudative) type. These findings were previously reported ${ }^{16} 18$ and seem to be related to some factors, such as a higher deposition of immature eggs and/or a delay of their maturation in the tissues.

It has been demonstrated ${ }^{3}$ that a chronic restriction of protein and calories by the use of semisynthetic diets induces, in experimentally infected mice, a decrease in egg-laying and a reduction of the granulomatous reaction in the tissues of the definitive host. It is also known that severe acute protein malnutrition suppresses the host's cellular immunity in schistosomiasis, causing a dramatic decrease in the granulomatous reaction'.

The formation of granulomas around eggs in the host's tissues is inhibited by several types of nutritional deficiences ${ }^{4}{ }^{24}$. The former authors showed that the egg load in the liver decreases as dietary protein is decreased, inhibition being greatest with a 50\% calorie-deficient diet. Akpom and Warren ${ }^{4}$ found that a significant proportion of the eggs recovered from mice fed $4 \%$ protein deficient and $50 \%$ calorie deficient diets was not viable.

There were no significant differences in splenic and intestinal lesions detected in our three groups of animals.

The role of periovular granuloma in schistosomiasis mansoni as a possible mechanism of the host to protect tissues against secretions from miracidium ${ }^{72}$, by attacking and destroying the miracidium itself, calls the attention to the importance of this phenomenon in undernourished hosts. It is also well accepted that this granulomatous reaction represents a delayed type of hypersensibilitys and that nutritional deficiency states lead frequently to some type of immunological dysfunction ${ }^{6}$. Since the formation of egg granulomas 
Coutinho EM, Abath FGC, Freitas LPCG, Salzano AC, Lapa MA, Campos FS, Melo EB. Liver and serum soluble protein changes and pathomorphology in undernourished mice with acute schistosomiasis mansoni. Revista da Sociedade Brasileira de Medicina Tropical 24:235-243, out-dez, 1991

is the main aggravating cause of the disease, studies on their characteristics and evolution are important topics for investigations ${ }^{8}$.

Further researches are recommended to estimate the extent to which improvement of the nutritional status of the host may contribute for decreasing the effects of schistosomiasis in mice and possibily in human beings residing in endemic areas of underdeveloped countries.

\section{RESUMO}

No presente estudo os pesos corporal, hepático e esplênico; a morfologia patológica do figado, baço e intestinos; e as modificações das proteinas solúveis hepáticas e séricas, foram os parâmetros investigados em camundongos albinos Suíços desnutridos e infectados com $\mathrm{S}$. mansoni. Os animais desnutridos não infectados apresentaram relaçzes figado/peso corporal e baço/ peso corporal com valores menores do que os animais controles (grupo caseina a 22,60\%). Camundongos infectados mostraram esses indices mais elevados, independentemente do tipo de dieta. $O$ subgrupo de camundongos desnutridos infectados apresentou, no figado, reação periovular exsudativa persistente. $O$ conteúdo de proteinas solúveis no figado e no soro também mostrou-se reduzido nos camundongos infectados desnutridos. Diferença significativa foi detectada quanto às gamaglobulinas, comparando-se animais infectados com não infectados alimentados com a dieta controle II, valores mais altos ocorrendo no grupo dos infectados. Especula-se que os efeitos da má nutrição podem ser mais prejudiciais ao hospedeiro do que aqueles provocados pelo S. mansoni.

Palavras-chaves: Schistosoma mansoni. Desnutrição. Protetnas. Camundongo.

\section{ACKNOWLEDGEMENTS}

We are indebted to Miss Lígia Pedrosa for her critical review and Miss Maria do Carmo Lacerda for typping the manuscript.

\section{REFERENCES}

1. Akpom CA. Suppression of granuloma formation around Schistosoma mansoni eggs in severe protein malnutrition: the role of the egg. Transactions of the Royal Society of Tropical Medicine and Hygiene 75:444-446, 1981.

2. Akpom CA. Schistosomiasis: nutritional implications. Reviews of Infectious Diseases 4:776782, 1982.

3. Akpom CA, Warren KS. The inhibition of granuloma formation around Schistosoma mansoni eggs. VI. Protein, calorie and vitamin deficiency. American Journal of Pathology 79:435-452, 1975.

4. Akpom CA, Warren KS. Calorie and protein malnutrition in chronic murine Schistosomiasis mansoni: effect on the parasite and the host. The Journal of Infectious Diseases 132:6-14, 1975.

5. Behmer OA, Tolosa EMC, Freitas Neto AG. Manual de técnicas para histologia normal e patológica. Editora da Universidade de São Paulo, São Paulo, 1976.

6. Beisel WR. Role of nutrition in immune system diseases. Comprehensive Therapy 13:13-19, 1987.

7. Brito T, Hoshino-Shimizu S, Silva LC, Kanamura H, Costa CM, Pinto PS. Immunopatology of experimental schistosome (S. mansoni) egg granulomas in mice-possible defence mechanisms mediated by local immune complexes. Journal of Pathology 140:17-28, 1983.

8. Chen MG, Mott KE. Progress in assessment of morbidity due to Schistosoma mansoni infection (A review of recent literature). Tropical Diseases Bulletin 85:1-56, 1988.

9. Compbell RM, Kosterlitz HW. The effect of dietary protein on the turnover of phospholipids, ribonucleic acid and desoxyribonucleic acid in the liver. Journal of Biological Chemistry 175:989990, 1948.

10. Coutinho EM. Relações hospedeiro - parasito na esquistossomose mansônica, em função da Dieta Básica Regional (estudo epidemiológico e anátomopatológico). Tese de doutorado, Centro de Ciências da Saúde da Universidade Federal de Pernambuco, Brasil, 1976.

11. Coutinho EM. Estado nutricional e esquistossomose. Revista da Sociedade Brasileira de Medicina Tropical XIII:91-96, 1979-1980.

12. Coutinho EM. Patobiologia da desnutrição nas doenças parasitárias. Memórias do Instituto Oswaldo Cruz 75:63-76, 1980.

13. Coutinho EM, Barbosa FS, Barbosa JM, Pessoa $\mathrm{D}$, Pinto RF, Oliveira PA, Rodrigues BA. Inquérito clínico-nutricional e antropométrico preliminar em áreas endêmicas de esquistossomose mansônica, no nordeste do Brasil. Revista da Sociedade Brasileira de Medicina Tropical VI:211236, 1972.

14. Coutinho EM, Costa LP, Salzano AC, Campos FS, Melo MEB, Lapa A. Níveis e tipos de proteínas 

protein changes and pathomorphology in undernourished mice with acute schistosomiasis mansoni. Revista da Sociedade Brasileira de Medicina Tropical 24:235-243, out-dez, 1991

alimentares e suas repercussões sobre a biologia do hospedeiro, na esquistossomose experimental (S. mansoni) do camundongo albino. In: Anais da

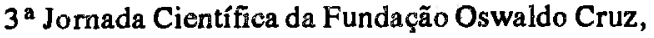
Rio de Janeiro p.454-455, 1985.

15. Coutinho-Abath $\mathbf{E}$. Influence of protein intake on the penetration of cercariae of Schistosoma mansoni in the skin of normal and experimentally infected mice. Revista do Instituto de Medicina Tropical de São Paulo 4:230-241, 1962.

16. Coutinho-Abath E. Observações preliminares sobre o padrão dietético em áreas endêmicas de esquistossomose mansônica. Jornal Brasileiro de Medicina 8:339-344, 1964.

17. Coutinho-Abath E. Esquistossomose mansônica e nutrição. Revista Brasileira de Malariologia e Doenças Tropicais XVI:233-253., 1964.

18. Coutinho-Abath E, Amaral JA, Barbosa JM. Alterações bioquímicas na esquistossomose mansônica humana, com especial referência ao metabolismo lipídico. Jornal Brasileiro de Medicina 11:157-168, 1966.

19. Coutinho-Abath E, Espírito Santo M, Barbosa JM, Mello SA. Padrão alimentar em áreas endêmicas de Esquistossomose mansônica, no Nordeste do Brasil. Revista Brasileira de Malariologia e Doenças Tropicais 16:553-589, 1964.

20. Coutinho-Abath E, Magalhães Filho A, Barbosa JM. Lesões hepáticas no camundongo albino experimentalmente infestado por Schistosoma mansoni e submetido a dietas de diferente teor protéico. Revista do Instituto de Medicina Tropical de São Paulo 4:311-322, 1962.

21. De Witt WB. Experimental Schistosomiasis mansoni in mice maintained on nutritionally deficient diets. I. Effects of a Torula yeast ration deficient in factor 3 , vitamin $E$, and cystine. Journal of Parasitology 43:119 128, 1957.

22. De Witt WB, Warren KS. Hepato-splenic schistosomiasis in mice. The American Journal of Tropical Medicine and Hygiene 8:440-446, 1959.

23. Gornall AG, Bardawell CG, David MJBC. Determination of serum protein by means of the biuret reaction. Journal of Biological Chemistry 177:751, 1949.

24. K auft RF, Warren KS. The effect of calori and protein malnutrition of both the parasite and the host in acute murine schistosomiasis mansoni. The Journal of Infectious Diseases 120:560-575, 1969.
25. Lago ES, Pessoa DCNP, Teodósio NR, Cabral Filho JE. Longevity and growth curve of chronically malnourished rats fed the Regional Basice Diet (RBD). In: Proceedings of the 2nd International Symposium of Nutrition, Recife p.40-41, 1988.

26. Lowry OH, Rosenbrough NG, Farr AL, Randall RJ. Protein measurement with the Folin - plenol reagent. Journal of Biological Chemistry 193:265275, 1951.

27. Moore DV, Yolles TK, Meleney HE. A comparison of common laboratory animals as experimental hosts for Schistosoma mansoni. Journal of Parasitology 35:156-170, 1949.

28. Ponce PN, Osório MB, Aragón FZ. DNA proteinas en el higado de ratas alimentadas com maiz: importância de expressar la concentración de proteinas hepáticas en función del DNA. Archivos Latino-Americanos de Nutrición 31:471-484, 1981.

29. Reis MG, Andrade ZA. Functional significance of periovular granuloma in schistosomiasis. Brazilian Journal of Medical Research 20:55-62, 1987.

30. Stephenson LS, Latham MC, Mlingi B. Schistosomiasis and human nutrition. Cornell International Nutrition Monograph Series $\mathrm{n}^{0} 16$, New York p. 1-21, 1986.

31. Tagle MA, Donoso G. Net protein utilization determined in short and long-term experiments with rats. Journal of Nutrition 87:173-178, 1965.

32. Teodósio NR, Lago ES, Cabral Filho JE, Castro RM, Varela RM, Campos FACS, Costa FBR, Guedes RCA, Silva AT. Dietary deficieney and malnutrition - 2. Effects of malnutrition induced by the Regional Basic Diet (RBD) on development and growth. In: Proceedings of the 1st International Symposium of Nutrition, Recife p.39-40, 1986.

33. Teodósio NR, Romani SAM, Lágo ES. Dietary deficiencies and malnutrition. 1- An experimental dietetic model. In: Proceedings of the 1 st International Symposium of Nutrition, Recife p.38, 1986.

34. Warren KS. The influence of treatment on the development and course of murine hepatosplenic Schistosomiasis mansoni. Transactions of the Royal Society of Tropical Medicine and Hygiene 56:510519, 1986.

35. Warren KS, Domingo EO, Cowan RBT. Granuloma formation around schistosome eggs as a manifestation of delayed hypersensitivity. American Journal of Pathology 51:735-748, 1967. 